\title{
Beyond the Confessional/Non-Confessional Divide-The Case of German Islamic Theological Studies
}

\author{
Jan Felix Engelhardt
}

check for updates

Citation: Engelhardt, Jan Felix. 2021. Beyond the Confessional/

Non-Confessional Divide-The Case of German Islamic Theological

Studies. Religions 12: 70.

https://doi.org/10.3390/rel12020070

Received: 6 November 2020

Accepted: 8 January 2021

Published: 21 January 2021

Publisher's Note: MDPI stays neutral with regard to jurisdictional claims in published maps and institutional affiliations.

Copyright: (c) 2021 by the author. Licensee MDPI, Basel, Switzerland. This article is an open access article distributed under the terms and conditions of the Creative Commons Attribution (CC BY) license (https:/ / creativecommons.org/licenses/by/ $4.0 /)$.
Academy for Islam in Research and Society, Frankfurt University, 60486 Frankfurt, Germany; engelhardt@aiwg.de

\begin{abstract}
This article focuses on the cross-disciplinary collaboration of Islamic theological studies, Islamic Studies, and integrative perspectives of professors in Islamic Theology in Germany. Based on extensive interviews with German Muslim professors in theological centers, Engelhardt argues that in Germany, where the Ministry of Education and Research established several centers for Islamic Theology, the theological scholarly community is too small to cover all areas of Islamic knowledge and therefore integrates knowledge from Islamic Studies into their research and teaching to a great extent. As a result, Islamic Studies constitutes the most important neighboring discipline to German Islamic Theology. In this article, he explores the question of how exactly German Islamic Theology negotiates this relation with Islamic Studies. The article will show how the debate between Islamic Theology and Islamic Studies_as articulated by professors from both disciplines-relates to the ongoing question of what constitutes or is understood as 'apt knowledge' by current 'academic knowledge production' and authority formation about 'the Islamic'.
\end{abstract}

Keywords: Islamic Theology; Islam in Europe; Islamic knowledge; insiderism; sociology of knowledge

\section{Introduction}

Islamic education and research at Western European universities is a growing phenomenon, as other contributions in this Special Issue tell. ${ }^{1}$ Against the backdrop of political and social discourses on Islam in Europe, it is no wonder that the education of Muslim academic and religious professionals attracts great attention inside and outside academia. The development of various forms of "academic Islamic education" - in the sense of researching, learning, and teaching about the Islamic tradition-takes place at (private) university departments in Germany, Austria, the Netherlands, Switzerland, the UK, and other countries, primarily under the label of Islamic theology or Islamic theological studies. " "Theological" here refers to research on, or education within, a specific religion that is somehow informed by and committed to its tenets and traditions. What these very different national contexts have in common is the effort to reflect upon Islam by academic means, usually with a strong focus on the situation in their country, and to offer Imam, teacher, and other specialist training at the university. A critical reflection here is highly necessary, given the pitfalls that Islamic education might stumble into on its way through the jungle of academia and other fields of knowledge production: In a science system that is based on the principle of critique of knowledge instead of its transmission (Stichweh 1994, pp. 57-60), the idea of merely transferring the "Islamic knowledge archive" (Schulze 2019, p. 21) into Western European university systems would very likely result in epistemological dead ends and met with

1 I would like to thank the anonymous reviewers for their valuable comments and suggestions on this paper.

2 I refer to the academic discipline at German universities as "Islamic Theology" and to Islamic education at other European countries as "Islamic theological studies". While in Germany Islamic Theology constitutes a distinct academic discipline, in other countries that is not the case due to the smaller amount of institutes and chairs. In that case, I suggest to speak of "epistemic communities" (Cross 2013) that conduct Islamic theological studies. 
massive disapproval by neighboring academic disciplines (Strohschneider 2013, p. 6). ${ }^{3}$ Also, the idea of squeezing the traditional system of Islamic knowledge into the mold of Christian Theologies might be tempting and could easily be read into the recommendations to establish Islamic Theology by the German Science Council (Wissenschaftsrat 2010). ${ }^{4}$ Yet, this would result in a "theologization" of Islam (Lohlker 2012, p. 117) in which central aspects of Islam as a religion would be deformed.

These pitfalls are especially deep in the German case, where the model of theology at public universities lies at the intersection of state, churches, and university. Germany, I therefore propose, serves as a litmus test to the question of whether or not the establishment of Islamic education in the form of a comprehensive academic discipline can fulfill the various expectations Muslim communities, neighboring academic disciplines, political actors, and the general society have. In Germany, as elsewhere, we notice that the new Islamic theological studies develop within an interdisciplinary setting that includes different, sometimes antagonistic partners of academic dialogue, which proves fruitful for the further development of the field.

Establishing Islamic knowledge production at Western European universities is a process reflected and accompanied by a number of scholars with different academic backgrounds and interests in this topic. There is the Christian theologian interested in the way his Muslim colleagues conceptualize comparable research areas such as text interpretation, systematic theology, or religious pedagogy. There is the scholar of sociology of science who analyzes the genesis of a new discipline and scientific community within the science system as a test case of theoretical propositions about the differentiation of scientific disciplines, autonomy, and heteronomy of the university or the construction of academic fields. Most notably, there is the scholar of Islamic Studies who observes her Muslim theological colleagues produce different research questions, paradigms, and findings of core subjects of her very own discipline. Hence, the scientific communities of Islamic theological studies that currently emerge in European countries meet with interest from scholars of other disciplines who provide a critical context to that development. This allows for reflecting the emergence of Muslim education in European academia from both inside and outside the new discipline.

One aspect that demands cross-disciplinary collaboration is that in any country, Islamic theological studies are too small to cover all areas of research and teaching on Islam. Even in Germany, where the Ministry of Education and Research established several centers for Islamic Theology and one can speak of a distinct academic discipline, the theological scholarly community necessarily integrates knowledge from Islamic Studies. This is also due to the long and rich academic history, methodological and theoretical expertise, and world-wide scholarly acceptance of German Islamic Studies, which as a result represent the most important neighboring discipline to German Islamic Theology.

But how exactly does German Islamic Theology negotiate its relation with Islamic Studies? The fact that most of the current professors of Islamic Theology were trained in Islamic Studies speaks for a close relation rooted in many scholars' individual academic biography.

3 Neighboring disciplines can be defined as social and cognitive units of academic knowledge production (Stichweh 2003, p. 7) that work on similar questions, problems or topics and therefore show a high level of interdisciplinary exchange, cooperation and competition. For a discipline that works on Islam from Islamic theological perspectives, Islamic Studies represent a neighboring discipline in various regards. Research areas such as the intellectual history of Islam, Islamic law, or contemporary Muslim societies are only some examples in which scholars of both Islamic Studies and Islamic Theology communicate, cooperate and compete. Ahmed's claim that scholars of Islamic Studies and Muslim theologians have been mutually contributing to defining Islam illustrates and shows that the reciprocal influence between Islamic Studies and Muslim theological thinking precedes the establishment of Islamic Theology as a discipline by more than a century (Ahmed 2016, pp. 81, 115-26). Christian Theologies may act as neighboring disciplines with regard to, for example, systematic theology, text studies or questions of comparative theology. The engagement of parts of Turkish Islamic theology (Illahiyat) with Christian theologies from the 1950s onwards, as the work of Wilkinson (2019, pp. 227-31) and Körner (2005) demonstrate, also shows the close relationship between both disciplines before the establishment of Islamic theological studies in Western Europe. For contemporary interdisciplinary work of these theologies, see for example Tatari (2017).

4 The council, for example, recommends the disciplinary organization of Islamic theological studies into a range of subdisciplines that resembles the system of Christian theologies: "Exegesis" (instead of tafsìr), "Systematic Theology (including Fundamental Theology, Dogmatics [instead of 'aqīda], Morals/Ethics, Islamic Ecumenism), Islamic Law and Jurisprudence, Practical 'Theology', Religious Education Studies" (Wissenschaftsrat 2010, p. 79). 
Yet, as academic disciplines working on the same subjects at the same time cooperate in research and compete for an epistemic authority inside and outside academia, as well as for funding and students, the relation becomes ambivalent. This ambivalence of cooperation and competition - which of course also exists within these disciplines-is intensified by a common conception that identifies an epistemic duality between Islamic Theology and Islamic Studies in form of an insider/outsider, confessional/non-confessional, or normative/descriptive dichotomy (see Council of Science and Humanities 2010; Reinkowski 2007, pp. 33-34). This duality is considered one of the leading differentiation marks between the two disciplines both inside and outside academia.

Against this backdrop, this paper will focus on the epistemic positions that professors of Islamic Theology in Germany take on Islamic Studies. The main question is whether or not the mentioned divisions between both disciplines prove theoretically fruitful when we look at the way Islamic Theology is currently establishing itself in the German science system.

The following points are based on a qualitative study I conducted about the first generation of professors for Islamic Theology (including its subdiscipline, Islamic religious education) between 2013 and 2015. At the then five centers for Islamic Theology at public German universities, I conducted semi-structured expert interviews with 12 of the 19 appointed professors. All of them identified as Muslim. The majority were male, and either they themselves or their parents had migrated to Germany from a dominantly Muslim country. These professors were-still are-both experts and institutional gatekeepers in the formative time of German Islamic Theology, and represent the outlook of their respective institute. At the time of the interviews, they had been appointed for one up to five years. ${ }^{5}$ In the interviews, they were asked their definition of Islamic Theology as an academic discipline, their take on confessional research, epistemic and functional insiderism, their stance towards Islamic Studies, and their self-concept as Muslim theologians at German universities. The interviews were analyzed and interpreted according to the Mayring (2008) method of content analysis, focusing on the inductive development of categories such as "normativity", "conveyance of values", "academic standards", "methods", "self-conception as theologian", "academic biographies" or "authority", Engelhardt 2017). ${ }^{6}$

\section{Islamic Theology at German Universities}

In 2011, the German Ministry of Education and Research announced five university institutes as centers for Islamic Theology at the universities of Erlangen-Nuremberg, Frankfurt am Main/Gießen, Münster, Osnabrück, and Tübingen. In a second announcement in 2019, the Humboldt University in Berlin and the University of Paderborn were also granted theological institutes. Along with a number of individual chairs at other universities, Islamic Theology in Germany in 2020 included about 40 professorships and around 80 Postdoctoral and PhD students. About 2500 students were enrolled, most of them female (Wagner and Dreier 2020).

When we look back at the time Islamic Theology had been established at German universities, the main case that has been made for the institutionalization of Islamic research and teaching in the form of a new discipline within the scientific system was its supposed

5 All interview partners were publicly known professors who had been given some sort of permission to teach Islamic Theology (idjāza $)$. This permission is given by confessional councils at the universities, made up of representatives of Islamic organizations, and it can be withdrawn if the council considers a professor ineligible to teach Islam. (This model is adapted from that of Catholic and Protestant Theology in Germany, where the churches have a similar right to give and withdraw their teaching permission.) Since some of the statements made by my interview partner could potentially qualifiy for the revocation of the $i \bar{d} j \bar{a} z a$, information on education, research area, university affiliation, age, gender, ethnic background, etc., are not given on specific interviewees.

6 In sum, about 70 subcategories were developed. Not all of them focus on the questions of the confessional/non-confessional in Islamic theology, but point out other aspects relevant to the establishment of Islamic Theology in Germany, such as the relation with Muslim organizations, the state and the public, the formation of a theological canon against the backdrop of traditional systems of Islamic knowledge or to key research questions of the discipline. These subcategories were further organized into four main categories consisting of "philosophy of science", "tasks", "stakeholders" and "Islamic theology". 
insider and confessional or denominational ${ }^{7}$ perspective on Islam (Council of Science and Humanities 2010, p. 72). While Islamic Studies, the argument goes, follows the academic paradigm of distanced, religiously neutral research and teaching about Islam, Islamic Theology in contrast approaches its subject from a believer's point of view. This argument has been brought forward by scholars from both Islamic Studies and Islamic Theology (see Khorchide and Schöller 2012).

Any epistemological discussion of the (non-)confessional in the study of Islam, however, will lead to the question of insiderism in knowledge production. In terms of knowledge and theories of truth, the question of academic insiderism is to which degree scholars who belong to a certain social group-such as a religious community, a nation, an ethnicity, a gender-have a better understanding of this group and its systems of meaning (for example worldviews, identities, interpretations of history) than scholars outside these groups. A monopolistic approach to knowledge argues that insiders have exclusive access to certain forms of knowledge that outsiders are unable to obtain. Sociologist Robert K. Merton labeled this approach to knowledge "strong insiderism", considering it the "epistemological principle that particular groups in each moment of history have monopolistic access to particular kinds of knowledge." (Merton 1972, p. 11) ${ }^{8}$ Indeed, in the Western study of Islam, the differentiation between insider and outsider approaches is legitimate and relevant both within the academic discourse and at the interchange of the scientific system and other subsystems of society. Strong insiderism, for example, could translate into the claim that only Muslim scholars were able to comprehend and interpret the Qur'ân. When the German Council of Science and Humanities called for the establishment of centers for Islamic Theology at public universities, some professors of Islamic Studies indeed feared several negative effects for the study of Islam at German universities: Firstly, a significant reduction of (Muslim) students from their departments. Secondly, the new discipline would establish itself as a closed community of Muslim insiders who do not engage in interdisciplinary research and communication. Thirdly, that a devotional and less critical mode of knowledge production would weaken academic standards. Sabine Schmidtke, then professor for Islamic Studies at the Free University Berlin, for example, claimed that Islamic Studies already cover the core areas of Islamic Theology sufficiently: Qur'an exegesis, Islamic law, or Islamic theology (kalām). A new discipline working on these fields solely from a confessional perspective would weaken the academic discourse on Islam and harm the existing cooperation between Muslim and non-Muslim scholars in the study of Islam (Schmidtke 2011).

\section{Insiderism, Normativity and Islamic Theology}

So which positions do professors of Islamic Theology in Germany take on the question of insiderism? Do they claim a monopolistic insiderism vis-à-vis Islamic Studies as their neighboring discipline, and establish themselves as a closed scientific community? In my study with professors of Islamic Theology, a majority indeed expressed the view that self-identifying as Muslim constitutes an epistemic differentiation to non-Muslim scholars and to Islamic Studies. According to them, this results in research interests that are deeply theologically informed - to make sense of God and Islam as His revealed religion. This interest is often narrowed down to exploring theological ways to make Islam at home in its German context. These research interests are based on epistemic premises that form

7 In much of the English written literature on Islamic theological studies in Germany and Western Europe, the terms "denominational" or "confessional" are used synonymously to refer to the fact that scholars in theological programs are supposed to identify as adherents of the religious tradition, or denomination, they research and teach, and are committed to its tenets and traditions in both their research and teaching (see Leirvik 2018; Berglund 2015, pp. 10-12; Ghaly 2010; Council of Science and Humanities 2010; Schepelern Johansen 2006). However, a substantial theoretical discussion of what exactly makes research and teaching of Islam confessional or denominational is still missing.

8 Monopolistic approaches to knowledge, however, have also worked the other way by arguing that only outsiders have the ability to fully, or objectively, understand certain phenomena. The history of Islamic Studies is full of examples for that and for the interconnection this idea of epistemic abilities has have with hegemony or blunt colonialism. See for a recent critical engagement with that Hallaq (2018, p. 3). In both ways, these approaches aim at constructing distinctive knowledge communities and establish epistemological hierarchies between them. 
points of departure of the Muslim scholars' theological journey. One central premise is, for example, that the Qur'an is the word of God as it has been revealed to the Prophet Muhammad, and not merely a text from late Antique Arabia whose authorship is unclear. This is maybe one of the most striking distinctions from paradigms of Islamic Studies-at least in Germany - and is necessary to allow for theological reasoning about the meaning and normative demands that the Qur'an poses to Muslims today.

Additionally, self-identifying as Muslim makes a scholar part of her or his discipline's research horizon-Islam and the Muslim community. While in the eyes of Muslim theologians, scholars of Islamic Studies ideally obtain an undecided distance towards Islam, they instead position themselves within the religious system of belief and practice and identify as members of the religious community that their discipline focuses on. Hence, as they make themselves part of the subject they work on, they do draw an epistemological and theoretical line between Islamic Theology and Islamic Studies. In that sense, the criterion that makes the study of Islam a confessional one is that of the scholar's positioning inside Islam. In contrast to Islamic Studies, this allows for normative claims from a Muslim perspective (see also Hughes 2015, p. 7).

Despite that, however, Muslim scholars I spoke to highlighted that these differentiations do not result in a clear-cut distinction between confessional/normative Islamic Theology and non-confessional/descriptive Islamic Studies. They underlined the importance of descriptive analysis in theological research on the one hand and pointed out normative approaches in Islamic Studies on the other. As Islamic Studies witnessed a whole range of different, antagonizing epistemic premises and research motives, so the argument, Muslim premises, and interests are not different from non-confessional but normative approaches such as feminism, Orientalism, or positivism, all of which have been applied within the realm of Islamic Studies (see also Agai 2015, pp. 189-90). In that sense, the challenge of normativity in research and teaching is nothing exclusive to theology, but omnipresent in the study of Islam. An epistemic framework that is tailored by religious convictions is therefore considered as only one manifestation of a normative approach to the study subject Islam, and does not pose more challenges to good scholarship than other epistemic-normative frameworks (see for example Hughes 2012).

As one professor stated, transferring the authority of the great scholars of the tradition without criticizing them would be the biggest challenge for an academic Islamic Theology:

“[ ... ] all scholars work on the basis of premises, assumptions, whatever. The same with theology, and God isn't even, I believe, the biggest problem here, but the biggest problem are the authorities [from within the tradition]."

Some professors in Islamic Theology claim that confessional approaches, research frameworks, and interests do not pose barriers to academic standards. When the research is well done, the argument goes, it is quite difficult to actually establish a difference between Islamic Studies and Islamic Theology based on insider/outsider epistemics. One reason is that critique and distance, too, can play-and should play — a crucial role in theological work, while the lack of it can also come into play within Islamic Studies. ${ }^{9}$ Therefore, while epistemic insiderism may constitute a key feature of Islamic Theology when it comes to research interests and premises, it does not materialize in a monopolistic form that excludes outsiders from its systems of knowledge.

Meanwhile, the academic criterion that arguments must be intersubjectively comprehensible develops as one of the initial paradigms of the young discipline. For many Muslim theologians in the German academic system, the option between a faith-based and an agnostic research approach is too limited to reflect their self-image properly, as they consider themselves first and foremost academics that try to hold up to the scientific

9 Recently, several authors have pointed towards theoretical shortcomings and normative projects in the study of Islam. Ahmed (2016, pp. 115-16), for instance, identifies an uncritical essentialization of Islam as a religion of law by both Muslim and non-Muslim scholars. Hallaq (2018, p. 3) points out the "confusion" about scholars' ethnic and religious backgrounds and their perceived ability to make an academically sound argument. 
criteria of the humanities. One theologian, for example, considers this duality not only unapt to contemporary modes of research but also alien to the Islamic tradition:

“When I open a commentary such as al-Ṭabarī [9th C. Qur'anic commentator], I see a philologist at work, a cultural studies scholar, an Islamic studies scholar and a historian, and only then the commentator. Our very own theological tradition inhabits a strong secular momentum, which can be found already in the Qur'an. We do not have this artificial enmity between holy and profane sciences with regard to church or anti-church institutions. We Muslims must not appropriate that."

The usage of the first-person plural in this quotation is noticeable, as the professor considers himself to be upholding part of a tradition that, in his opinion, in great parts is based on confessionally neutral knowledge. Sticking to the rules of the university may therefore level the epistemic differences between confessional and non-confessional disciplines. As one professor argued, a theological argumentation at the university has to be intersubjectively comprehensible:

"[It] has to be understandable for anyone. If I accomplish that, then what I do is scholarship. That is the only thing. [ ... ] [W] hat is written in the Qur'an, I have to be able to communicate that. In a way that even someone who doesn't believe in it at least admits that it is okay that I do."

Another professor emphasized that Islamic Theology has to fulfill academic criteria like any other academic discipline:

"For example, it cannot be that you produce Islamic theological contributions, or papers, or publications or research which does not comply to international norms. That is the most important thing at all. Therefore I do not see a big difference, saying: Here we have Islamic Theology which produced this article, and here we have another discipline. [ ... ] the rules of research apply to anyone."

One Muslim theologian bluntly stated that the differentiation between an insider Islamic theology and an outsider Islamic Studies is based on a "fake discourse" on epistemic boundaries between the two disciplines. This becomes clear when we look at the publications Muslim theologians produced so far: Which authors, apart from the scholarly authorities of the Islamic tradition, do they refer to? Outside the Islamic tradition, the most often cited authors stem from Islamic Studies. This indicates that Islamic Theology does not establish itself as a closed epistemic community, but heavily relies on academic knowledge that Islamic Studies provide. In many cases, it forms the basis for further theological conclusions (see Engelhardt 2016).

Across the disciplinary aisle, the rejection of a clear-cut distinction meets like-minded Islamic Studies scholars who either decline Islamic Studies' limitation to the descriptive analysis of Islam or consider any study of Islam as part of the Islamic intellectual history. Professor for Islamic Studies at the Free University in Berlin Gudrun Krämer, for example, underlines that both Islamic Theology and Islamic Studies "claim authority based on knowledge" and render judgments on questions about Islam (Krämer 2011, pp. 110-11). For Marco Schöller, professor for Islamic history at Münster University, research in Islamic Studies is even a continuation of the Islamic tradition, as every scholar working on Islam becomes part of its history of ideas (Schöller 2000, pp. 105-6). One effect of the mutual openness is that a number of PhD-students in Islamic Theology are co-supervised by a professor from Islamic Studies, for example in the fields of text studies on the Qur'an, the history of theological debates, Hadith studies, or Islamic law.

\subsection{Islamic Theology as a Hybrid Discipline}

On the one hand, Islamic Theologians indeed follow research interests that are informed by their religious belief and the motivation to make Islam at home in the German context. They also are currently establishing academic paradigms rooted in a religious understanding of Islam, including its main sources, histories of origin, and theological 
frameworks. In these ways, Islamic Theology is differentiated from Islamic Studies. On the other hand, they overwhelmingly refuse to be limited to the "theological realm" of the study of Islam, call for open borders between the two disciplines, and make great use of Islamic Studies-sometimes to the extent that students question their Muslimness.

As it merges knowledge, theories, and methods from Islamic systems of knowledge with Islamic Studies, I argue, Islamic Theology develops as a hybrid discipline. It is neither exclusively based on classical modes of Islamic knowledge production, nor merely does it add knowledge, theories, and methods from Islamic Studies to it in a way that leaves them clearly distinguishable within a theologian context. ${ }^{10}$ Islamic Theology establishes a new form of knowledge production that merges existing modes of the study of Islam into an autonomous academic field, and it is, therefore, able to overcome the divide between insider and outsider or confessional and non-confessional approaches.

This academic hybridity had its origins already in Islamic Studies, where great parts of the theological faculty have been trained. Several professors underline that their work had already been informed in Islamic Studies by research interests that can be called theological because of their epistemic framework or them having a Muslim auditorium outside academia in mind. As one professor narrates, already as a scholar in Islamic Studies, his interest was to cater to the needs of the Muslim community in Germany:

"Within the scope [ ... ] of my research [in Islamic Studies], I looked into the subject of [Qur'anic Studies ${ }^{11}$ ]. And then the interest emerged ... I felt that in this area almost nothing, I mean barely anything was being done, although there are many Muslims living in Germany and there was slowly an Islamic discourse developing, but not on the level or according to the expectations of Muslims in Germany."

Yet, it has to be mentioned that the research area in the discussion here has, in fact, been covered quite extensively by Islamic Studies. Therefore, the professor's diagnosis does not hint at a neglected field of research. Instead, it illustrates, that in his view, Islamic Studies did not cater to the German Muslim communities' needs-why would they, given that to my knowledge Islamic Studies have rarely identified German Muslims as a relevant audience. ${ }^{12}$ The professor here expresses his early desire to reflect upon Islam according to the needs and expectations of German Muslims. His narration here shows one point where Islamic Studies and Islamic Theology part: the orientation towards non-academic audiences which in turn informs the scholars' research interests.

Another professor, who had been employed in Islamic Studies before being appointed in Islamic Theology, uses the metaphor of changing one's citizenship in order to illustrate that his academic identity easily fits both Islamic Studies and Islamic Theology:

"For me, these identities aren't a problem really, I am used to that from my nationality, because, the first [20] years of my life I have been Turkish, because I had only the Turkish passport, and after that I became German, because I only have the German passport. For me these labels you get aren't essential. I felt as kind of a German Turk before and after. And in the same way I had been an academic, a scholar interested in religion, working about religion, and I am still now."

Asked about his self-identification as a scholar, he considers himself a historian and a theologian. With this hybrid identity as an academic, he does not stand alone: A number of professors I talked to identify as, for example, theologian and educationalist, sociologist, philosopher, or linguist. This allows for two interpretations: One, that the transition to

10 Hybrid disciplines can be defined as "interstitial cross disciplines" that merge existing areas of research from different disciplines into a new one (Klein 2010, p. 21).

11 For reasons of anonymity, the research area has been altered here.

12 Islam and Muslim communities are of course constitutive research objects of Islamic Studies. Yet, when considering non-academic audiences of Islamic Studies, the extensive analysis, interpretation and classification of the religion, social practices and attitudes of Muslims do not address those under scrutiny. See for an overview Tezcan (2003) and also some remarks on the role of Islamic Studies outside academia in Freitag (2007, pp. 80-81). 
Islamic Theology did not pose great problems to their methodologies and research agendas, since without further ado they transferred their academic identity into the new discipline. Two, the self-description as theologian and X suggests that they do not merely combine approaches of different disciplines in the usual interdisciplinary way, where one could easily distinguish between theories and methods of one discipline and the other, but merge several disciplinary modes of knowledge production into a new one.

Hence, where Islamic Theology takes part in educating and training Muslims in Germany, it does so from a perspective that brings together confessional and non-confessional approaches. This is also where Islamic Theology unfolds its innovative epistemological potential. It creates an intellectual space within the university where theories and methods of the humanities meet the knowledge traditions of Islam, where different epistemes clash, compete, and merge. This promises theological innovations that have the potential to hold up to expectations from both traditional and interdisciplinary perspectives. For this, however, knowledge of Islamic Studies must be flexible enough to be reconciled with theological epistemes, the Islamic tradition for its part has to go through the eye of the needle of modern critique. Two quotations may illustrate the notion that the tradition does not inhabit an epistemic relevance for Islamic Theology sui generis. As one professor claims:

"I am not someone who points at a scholarly tradition and says: I base my argument on this and that school. I prefer to stand up and say: I thought about that topic and came to the conclusion that one should think about it this or that way. You will get confronted with the tradition soon enough."

One professor underlines:

"You know, someone like al-Shāfí 'ì, I bow to them. [ ... ] But that does not mean that I must not reappraise what they say, or understand them as children of their own time. I may. [ ... ] I am still a Hanafi, because Abu Hanifa [ ... ] convinces me with his arguments. He argues in a way, this is just... [pause]. But there are passages where he does not convince me, where Šăfi'î is just stronger, where he [Abu Hanifa] loses. [ ... ] In this respect, these old figures are not an authority for me anymore. They do not work as such anymore, instead if an arguments makes sense, this argument becomes the authority, because it convinces you, if you like it or not."

Suffice to say that this critical stance towards the tradition creates tensions between scholars and those students and representatives of Muslim organizations who expect Islamic education at the German university to adopt traditional models of Islamic education. Hence, to what extent students of Islamic Theology comply with their discipline's hybrid identity is still unclear and awaits further research. It will be interesting to see where students expect an Islamic education at the university that primarily continues traditional modes of Islamic knowledge production, and where they acknowledge the need to merge confessional with non-confessional approaches in research and teaching.

One could argue, however, that this theological superstructure that Muslim scholars put upon knowledge from Islamic studies constitutes such a normative deviation from Islamic Studies that it makes a separate discipline necessary. In that sense, the epistemic divide would be reason enough to split the general study of Islam into a confessional and a non-confessional discipline. Yet, looking at other academic fields in which Islam is studied, one can detect great flexibility in terms of the range of academic paradigms and research interests. In the US, for example, a considerable epistemic community of Muslim scholars researches and teaches Islam in a more or less openly theological way within Islamic Studies and other related disciplines. Antagonizing, competing theories of truth do not necessarily induce the emergence of another autonomous discipline. At least in Germany, the political blueprint of arranging religious knowledge production at the university has been the reason that triggered the formation of Islamic Theology. 


\subsection{Functional Insiderism}

Until now, I hope to have made the point that one cannot apply the insider/outsider dichotomy on Islamic Studies and Islamic Theology without doing the academic selfconception of Muslim theologians an injustice. More important, I propose, is the different function that Islamic Theology and Islamic Studies in Germany serve, and I think the same is true for other countries that establish Islamic knowledge production at their universities.

I will not go into detail about the tasks that Islamic Studies' scholars in Germany ascribed to their discipline - there exists a body of literature and discussion on that (see for example, Schöller 2000; Richter-Bernburg 2003; Heine 2010; Jung 2011). Nevertheless, reflecting upon Islam from a Muslim point of view, further developing Muslim theological questions and ideas, training pedagogical and religious personnel for Muslim communities and "speaking for Islam" (Krämer and Schmidtke 2006) in public debates have never been among them-and this is where Islamic Theology comes in.

While Islamic Studies is expected to self-identify as a discipline that, in the widest, sense provides knowledge on Islam, Islamic Theology is expected to contribute to the advancement of Muslim thinking and education. The academic and societal role of the discipline's scholars is primarily to further develop the religious reflection upon Islam, to train teachers for Islamic religious education and personnel for the Muslim communities, and to spread Islamic knowledge in academic and public (Muslim) discourses. An insider dimension is a prerequisite for providing theological orientation for audiences outside academia - mainly the Muslim community in Germany. This dimension aims at the function of theology to produce academic knowledge that in the German university system no other discipline is considered to be able to provide. Giving answers to religious questions on life and death, values, and behavior, all within the setting of being a Muslim in German society. In that sense, Islamic Theology confirms its specific theological assignment from German science policy. As the Council of Science and Humanities puts it, theology follows the interest in setting norms and making sense of human existence (Council of Science and Humanities 2010, p. 51). Islamic Theology bases this on an Islamic epistemological framework, which differentiates itself from both non-confessional Islamic Studies and Philosophy. Hence, the institutionalization of Islamic theological perspectives allows Muslim scholars to openly speak to an Islamic audience and to gain access to public debates as Muslim academics. All of these are roles that shape the self-concept of Muslim theologians in Germany. It is these roles-not the discipline's epistemic differentiationthat triggered the establishment of Islamic Theology as an autonomous discipline and legitimizes its existence within the science system, as it quite substantially departs from the function Islamic Studies' scholars and institutions fulfill.

This is also where, besides its epistemic challenges when it comes to confessional axioms, critics spud in and problematize the political functionalization of an academic discipline (Amir-Moazami 2016). Muslim communities also sensed early on the political motive to set up an Islamic theological discipline that serves the project in forming a Muslim subject. These critiques are justified, as they point out a state interest that potentially goes beyond the equal treatment or positive neutrality towards religions that the German state is obliged to guarantee. However, critics such as Farid Esack, who described the establishment of Islamic Theology as an "assimilationist project" that German Muslims deliberately join, tend to neglect the agency potential of Muslim academics involved (Esack and Mende 2014). Indeed, Muslim scholars I interviewed ascribed theology to the function of opposing fundamentalism in Islam. In that perspective, theology takes up the assignment of providing counter interpretations of Islam by delivering a system of knowledge and teaching that is both rooted in Islamic traditions and opens a path to make Islam at home in Western Europe. This dimension can be-and has been- especially criticized for being part of the general endeavor to create a domesticated Muslim subject that is first and foremost compatible with German society and its demands for a liberal, enlightened Islam. Most professors I interviewed are, however, quite aware of this pitfall and do not consider themselves as pawns of this game. They do not conceptualize Islamic 
Theology primarily as an instrument of domestication, as a bulwark against fundamentalism that protects German society against Muslim zealots. Instead, a common motive is to save mainstream Islam from its own radical periphery by preserving and developing its traditions within a new epistemological and social environment. Different from leaders or spokespersons of a Muslim community, Muslim theologians make their argument not on the representation of a social collective, but based on their theological work. The intellectual liberty required for that is in turn guaranteed by the context of the university.

\section{Conclusions}

The German case has been identified as a litmus test to the question of whether or not Islamic Theology at the university can satisfy the expectations of its various external stakeholders-neighboring disciplines within the science system, Muslim communities, society. The test is still running, I propose, as Islamic Theology in Germany is still in the process of establishing itself and finding its role as an academic discipline that researches and teaches Islam and trains Muslim professionals. Fact is, however, that when it comes to the relation to Islamic Studies, Islamic Theology does not follow along the line of confessional vs. non-confessional research and teaching, but transforms knowledge from Islamic Studies and the Islamic tradition into a new, hybrid body of academic knowledge. Hence, Islamic Theology does not restrict itself to being a strict insider discipline, as discussions on insider/outsider approaches in the study of Islam would suggest. With regard to academia, the integration of great parts of knowledge from Islamic Studies allows Islamic Theology to hold up to interdisciplinary communication and inter-subjectivity. With regard to stakeholders who champion a theological approach that is based first and foremost on the continuation of traditional production modes and systems of Islamic knowledge - parts of the student body and Muslim organizations-this, however, evokes mistrust and potentially limits the effects of Islamic Theology has outside academia. For non-theological disciplines, limited effects on stakeholders outside the universities may pose a neglectable problem. Due to its functionality as a discipline that is supposed to train Muslim professionals, Islamic Theology, however, is in need of acceptance of great parts of the Muslim community in Germany. Therefore, reconciling close proximity to Islamic Studies on the one side and the acceptance of the Muslim community will be a challenging task for Muslim theologians in the future.

Funding: This research received no external funding.

Institutional Review Board Statement: Not applicable.

Informed Consent Statement: Informed consent was obtained from all subjects involved in the study.

Data Availability Statement: Not applicable.

Acknowledgments: The author would like to thank the anonymous reviewers for their valuable comments and suggestions on this paper.

Conflicts of Interest: The author declares no conflict of interest.

\section{References}

Agai, Bekim. 2015. Introducing Islamic Theological Studies at German Universities: Secular Expectations and Epistemic Rearrangements. Toronto Journal of Theology 31: 181-95. [CrossRef]

Ahmed, Shahab. 2016. What is Islam? The Importance of Being Islamic. Princeton: Princeton University Press.

Amir-Moazami, Schirin. 2016. Die 'muslimische Frage' in Europa. Politische Aporien der Anerkennung unter liberal-säkularen Bedingungen. In Politische Aporien. Akteure und Praktiken des Dilemmas. Edited by Philipp Hubmann, Martin Gronau and Marie-Luisa Frick. Vienna: Turia+Kant, pp. 111-36.

Berglund, Jenny. 2015. Publicly Funded Islamic Education in Europe and the United States. The Brookings Project on U.S. Relations with the Islamic World Analysis Paper. Washington, DC: The Brookings Institution, vol. 21, pp. 1-49.

Council of Science and Humanities. 2010. Recommendations on the Advancement of Theologies and Sciences Concerned with Religions at German Universities. Berlin: Council of Science and Humanities.

Cross, Mai'a Keapuolani Davis. 2013. Rethinking epistemic communities twenty years later. Review of International Studies 39: 137-60. [CrossRef] 
Engelhardt, Jan Felix. 2016. Wer verweist auf wen? Was Zitationen über den Fachdiskurs der Islamisch-Theologischen Studien verraten. Frankfurter Zeitschrift für Islamisch-Theologische Studien 3: 185-94.

Engelhardt, Jan Felix. 2017. Islamische Theologie im Deutschen Wissenschaftssystem. Ausdifferenzierung und Selbstkonzeption einer neu Etablierten Wissenschaftsdisziplin. Wiesbaden: Springer Research.

Esack, Farid, and Claudia Mende. 2014. Pluralist Societies Are about Give and Take. Qantara.de. September 22. Available online: https:/ / en.qantara.de/content/interview-with-farid-esack-pluralist-societies-are-about-give-and-take (accessed on 8 January 2021).

Freitag, Ulrike. 2007. Islamwissenschaft aus der Sicht eines außer-universitären Forschungsinstituts: Orient als Islam? In Das Unbehagen in der Islamwissenschaft: Ein Klassisches Fach im Scheinwerferlicht der Politik und der Medien. Edited by Maurus Reinkowski and Abbas Poya. Bielefeld: Transcript, pp. 71-82.

Ghaly, Mohammed. 2010. Training Imams in Europe: The Challenges of Developing a Unified Program—Leiden University as a Study Case. Hikma: Journal of Islamic Theology and Religious Education 1: 57-70.

Hallaq, Wael B. 2018. Restating Orientalism. A Critique of Modern Knowledge. New York: Columbia University Press.

Heine, Peter. 2010. Aus dem Schatten heraus. Islamwissenschaften im Wandel. Herder Korrespondenz Spezial 64: $137-41$.

Hughes, Aaron. 2012. Theorizing Islam: Disciplinary Deconstruction and Reconstruction. Durham: Acumen Publishing.

Hughes, Aaron. 2015. Islam and the Tyranny of Authenticity. An Inquiry into Disciplinary Apologetics and Self-Deception. Sheffield: Equinox Publishing.

Jung, Dietrich. 2011. Orientalists, Islamists and the Global Public Sphere: A Genealogy of the Modern Essentialist Image of Islam. Sheffield and Oakville: Equinox Publishing.

Khorchide, Mouhanad, and Marco Schöller, eds. 2012. Das Verhältnis zwischen Islamwissenschaft und Islamischer Theologie. Beiträge der Konferenz Münster, 1-2 Juli 2011. Münster: Agenda Verlag.

Klein, Julie Thompson. 2010. A Taxonomy of Interdisciplinarity. In The Oxford Handbook of Interdisciplinarity. Edited by Robert Frodeman. Oxford: Oxford University Press, pp. 15-30.

Körner, Felix. 2005. Revisionist Koran Hermeneutics in Contemporary Turkish University Theology. Rethinking Islam. Wurzburg: Ergon.

Krämer, Gudrun. 2011. Islamische Reform und gesellschaftliche Erneuerung oder: Was ist ,kritische Islamwissenschaft'? In Das Verhältnis zwischen Islamwissenschaft und Islamischer Theologie. Beiträge der Konferenz Münster, 1-2 Juli 2011. Edited by Mouhanad Khorchide and Marco Schöller. Munster: Agenda Verlag, pp. 109-14.

Krämer, Gudrun, and Sabine Schmidtke, eds. 2006. Speaking for Islam: Religious Authorities in Muslim Societies. Leiden: BRILL.

Leirvik, Oddbjørn. 2018. Interreligious University Theologies, Christian/Islamic. Islam and Christian-Muslim Relations 29: 509-23. [CrossRef]

Lohlker, Rüdiger. 2012. Islamwissenschaften-Bewegungen und Deterritorialisierungen. In Das Verhältnis zwischen Islamwissenschaft und Islamischer Theologie. Beiträge der Konferenz Münster, 1-2 Juli 2011. Edited by Mouhanad Khorchide and Marco Schöller. Munster: Agenda Verlag, pp. 115-18.

Mayring, Philipp. 2008. Qualitative Inhaltsanalyse: Grundlagen und Techniken. Weinheim: Beltz.

Merton, Robert King. 1972. Insiders and Outsiders: A Chapter in the Sociology of Knowledge. American Journal of Sociology 78: 9-47. [CrossRef]

Reinkowski, Maurus. 2007. Islamwissenschaft und relevante Redundanz. In Das Unbehagen in der Islamwissenschaft: Ein klassisches Fach im Scheinwerferlicht der Politik und der Medien. Edited by Maurus Reinkowski and Abbas Poya. Bielefeld: Transcript, pp. 19-36.

Richter-Bernburg, Lutz. 2003. Islamwissenschaft. In Wozu Geisteswissenschaften? Kontroverse Argumente für eine überfällige Debatte. Edited by Florian Keisinger and Steffen Seischab. Frankfurt and New York: Campus, pp. 124-30.

Schepelern Johansen, Birgitte. 2006. Islam at the European Universities. Copenhagen: University of Copenhagen.

Schmidtke, Sabine. 2011. Theologie kann Religionswissenschaft nicht ersetzen. Der Tagesspiegel. January 3. Available online: https: //www.tagesspiegel.de/meinung/gastkommentar-theologie-kann-religionswissenschaft-nicht-ersetzen/3687832.html (accessed on 8 January 2021).

Schöller, Marco. 2000. Methode und Wahrheit in der Islamwissenschaft. Prolegomena. Wiesbaden: Harrassowitz.

Schulze, Reinhard. 2019. Islam, Islamic Knowledge and the Modern Order of Authority. In Islam in Knowledge-Power Relations. A Challenge for Muslim Theologies? Edited by Jan Felix Engelhardt and Hansjörg Schmid. Berlin: EB-Verlag, pp. 15-38.

Stichweh, Rudolf. 1994. Wissenschaft, Universitat, Professionen. Soziologische Analysen. Frankfurt: Suhrkamp.

Stichweh, Rudolf. 2003. Differentiation of Scientific Disciplines: Causes and Consequences. In Encyclopedia of Life Support Systems (EOLSS). Paris: UNESCO, pp. 1-8.

Strohschneider, Peter. 2013. Pluralisierungszumutungen und Islamische Theologie. Religiöse Pluralisierung, akademische Theologie und staatliche Universität. In Theologie(n) an der Universität. Akademische Herausforderungen im säkularen Umfeld. Edited by Walter Homolka and Hans-Gert Pöttering. Berlin: de Gruyter, pp. 1-8.

Tatari, Muna. 2017. Using Comparative Insights in Developing Kalām. A Personal Reflection on Being Trained in Comparative Theology. In How to Do Comparative Theology. Edited by Francis Xavier Clooney and Klaus von Stosch. New York: Fordham University Press, pp. 188-205.

Tezcan, Levent. 2003. Das Islamische in den Studien zu Muslimen in Deutschland. Islamic Issues in Studies on Muslims in Germany. Zeitschrift für Soziologie 32: 237-61. [CrossRef] 
Wagner, Constantin, and Lena Dreier. 2020. Wer Studiert Islamische Theologie? Ein Überblick über das Fach und seine Studierenden. Frankfurt am Main: Academy for Islam in Research and Society. Available online: https://aiwg.de/wp-content/uploads/2020 /03/Wer-studiert-islamische-Theologie_Expertise.pdf (accessed on 8 January 2021).

Wilkinson, Taraneh R. 2019. Dialectical Encounters. Contemporary Turkish Muslim Thought in Dialogue. Edinburgh: Edinburgh University Press.

Wissenschaftsrat. 2010. Recommendations on the Advancement of Theologies and Sciences Concerned with Religions at German Universities. Köln: Wissenschaftsrat. 